\title{
Pelatihan Pemanfaatan Limbah Jerami Sebagai Media untuk Budidaya Jamur Tiram Putih
}

\author{
Meitiyani $^{1}$, Susilo $^{2 *}$, Maryanti Setyaningsih ${ }^{3}$ \\ Universitas Muhammadiyah Prof. Dr. HAMKA ${ }^{1,2,3}$ \\ meitiyani@uhamka.ac.id ${ }^{1}$, susilo@uhamka.ac.id²*, maryantisetyaningsih@gmail.com³
}

\begin{abstract}
Oyster mushroom cultivation (Pleurotus sp.) is very dependent on the environment and planting media. Media such as straw is an alternative substitute for wood powder because it is available in abundance. The purpose of this activity is to provide skills in mushroom cultivation by utilizing straw waste to PKK mothers in Cigaragol village, Ciulengsi, Bogor. This skill about oyster mushroom cultivation needs to be disseminated to the wider community to overcome the lack of supply of oyster mushrooms on the market. The method used in this activity is by lecturing, discussion and practice. The results of the training activities of white oyster mushroom cultivation have increased the knowledge and skills of the community by $71.9 \%$ which includes the introduction of $31.6 \%$ white oyster mushrooms, the benefits of white oyster mushrooms 52.6\%, $100 \%$ white oyster mushroom habitat, wood powder media for cultivation of white oyster mushrooms $57.9 \%$, straw media as an alternative to $100 \%$ white oyster mushroom cultivation and white oyster mushroom cultivation technique $89.5 \%$. The training activities greatly helped improve the knowledge and skills of cultivating the white oyster mushroom of the community and potentially increase the income of the community.
\end{abstract}

Keywords: Mushroom Cultivation; White Oyster Mushrooms; Sawdust; Straw.

\begin{abstract}
Abstrak
Budidaya jamur tiram (Pleurotus sp.) sangat bergantung pada lingkungan dan media tanam. Media seperti jerami merupakan alternatif pengganti media serbuk kayu karena tersedia melimpah. Tujuan dari kegiatan ini adalah untuk memberi ketrampilan budidaya jamur dengan memanfaatkan limbah jerami kepada ibu-ibu PKK di desa Cigaragol, Ciulengsi, Bogor. Ketrampilan tentang budidaya jamur tiram ini perlu disebarluaskan kepada masyarakat luas untuk mengatasi kekurangan pasokan jamur tiram di pasar. Metode yang digunakan dalam kegiatan ini adalah dengan cara ceramah, diskusi dan praktek Hasil dari kegiatan pelatihan budidaya jamur tiram putih telah menambah pengetahuan dan ketrampilan masyarakat sebesar 71,9 \% yang meliputi pengenalan istiah jamur tiram putih sebesar 31,6\%, manfaat jamur tiram putih sebesar 52,6\%, habitat jamur tiram putih $100 \%$, media serbuk kayu untuk budidaya jamur tiram putih 57,9\%, media jerami sebagai alternatif budidaya jamur tiram putih $100 \%$ dan teknik budidaya jamur tiram putih $89,5 \%$. Kegiatan pelatihan sangat membantu meningkatkan pengetahuan dan ketrampilan budidaya jamur tiram putih masyarakat dan berpotensi menambah penghasilan masyarakat.
\end{abstract}

Kata Kunci: Budidaya Jamur; Jamur Tiram Putih; Serbuk Kayu; Jerami. 


\section{A. PENDAHULUAN}

Kecamatan Cileungsi merupakan salah satu daerah industri di kawasan Jabodetabek, yang terdiri dari 12 desa, salah satunya adalah desa Mekarsari. Desa Mekarsari terkenal dengan taman wisata berupa pusat pelestarian buah-buahan tropika terbesar di dunia seluas 264 ha. Salah satu kelurahan dari desa Mekarsari ini adalah kelurahan Cigarogol yang berlokasi tepat berada di seberang Taman Buah Mekarsari. Perkampungan ini mempunyai luas 19 ha dan dalam rencana pembangunannya akan dipertahankan sebagai wilayah penduduk asli yang akan dikelilingi pembangunan perumahan real estate. Penduduk Kampung Cigarogol berjumlah sekitar 5400 jiwa terbagi atas 3 Rukun Warga (RW) dan 9 Rukun Tangga (RT). Jumlah penduduk di RT. 01 sekitar 105 jiwa dan RT. 04 ada sekitar 55 jiwa. Kedua RT tersebut ada di wilayah RW. 02. Dari jumlah tersebut yang menjadi sasaran kegiatan pengabdian kepada masyarakat ini adalah kelompok ibu-ibu rumah tangga yang tergabung dalam kelompok PKK. Ibu-ibu PKK di kampung Cigarogol tersebut rata-rata tidak memiliki pekerjaan yang tetap selain menjadi ibu rumah tangga. Masalah lain muncul ketika dihadapkan pada tataran nilai perekonomian.

Perubahan lingkungan sosial dan ekonomi di wilayah ini membawa perubahan pada tatanan sosial penduduk kampung Cigarogol. Secara ekonomi, beberapa kepala keluarga terutama yang mempunyai pendidikan minimal SMA menerima dampak positif dengan bekerja sebagai karyawan di lokasi wisata dan industri/pabrik. Sementara sebagian masyarakat yang tidak mendapat kesempatan bekerja sebagai karyawan, tetap menjalani pekerjaan sebagai petani sawah dan menghasilkan jerami sebagai limbah yang dapat dimanfaatkan. Pendapatan penduduk yang bekerja sebagai karyawan di lokasi wisata dan industri/pabrik cukup membawa perubahan ekonomi keluarga. Akan tetapi bagi penduduk yang mempunyai tingkat pendidikan SD dan SMP mengalami hambatan dalam mencapai penghasilan yang memadai di tempat kerja mereka. Posisi mereka terbatas dan hanya berperan sebagai buruh saja di pabrik atau industri yang memperkerjakannya. Akibatnya tingkat ekonomi mereka tidak banyak berubah dan mengalami kendala keuangan dalam memenuhi kebutuhan keluarga seperti kesehatan dan pendidikan.

Begitu juga penduduk yang tetap berprofesi sebagai petani penggarap sawah sebagian besar merasakan hal yang sama, kebutuhan keluarga cukup berat dipikul mereka dengan luas areal sawah yang semakin terbatas. Oleh sebab itu di daerah ini masih banyak usia produktif yang putus sekolah sampai tingkat SD dan SMP karena kendala ekonomi. Wanita usia tua dan sebagian wanita usia produktif yang putus sekolah di tingkat SD dan SMP menghabiskan waktunya untuk urusan rumah tangga dan yang pasti tidak memiliki penghasilan tambahanuntuk memenuhi kebutuhan mereka. Mereka mengandalkan penghasilan dari kepala keluarga yang jumlahnya kadang kurang untuk memenuhi kehidupan sehari-hari. Penghasilan keluarga yang minim menjadikan perlunya upaya membantu ekonomi keluarga dengan memanfaatkan waktu luang wanita yang tidak bekerja.

Berdasarkan hasil survey kondisi dan kebutuhan masyarakat desa Cigarogol RT. 01 dan RT. 04 RW. 02, permasalahan yang ada di dalamnya adalah lebih dari 50\% wanita di daerah ini bekerja sebagai ibu rumah tangga. Suami sebagai tulang punggung keluarga mengalami hambatan dalam mencapai penghasilan yang memadai di tempat kerja 
mereka. Posisi mereka terbatas dan hanya berperan sebagai buruh di pabrik atau industri yang memperkerjakannya dengan pendapatan 2 juta sampai 3,5 juta setiap bulan. Ketrampilan ibu-ibu PKK belum dapat membantu mengangkat perekonomian keluarga. Limbah jerami di daerah sekitar perkampungan ini belum dimanfaatkan secara maksimal. Persoalan yang dijadikan prioritas di mitra ibu-ibu PKK RT. 01 dan 04 adalah kurangnya keterampilan yang dapat menjadikan ibu-ibu lebih produktif, sehingga dapat menambah penghasilan untuk membantu masalah ekonomi keluarga.

Salah satu usaha untuk mengatasi masalah tersebut adalah memberikan pelatihan ketrampilan melalui kegiatan pelatihan budidaya jamur tiram (Pleurotus sp.). Wilayah Cigarogol yang relative sejuk sangat cocok untuk dijadikan tempat budidaya jamur tiram. Kegiatan pengabdian kepada masyarakat ini diharapkan dapat mengatasi masalah ekonomi waga di desa tersebut. Selain itu, daerah Cigarogol juga memiliki sumber alam yang melimpah untuk dijadikan media tanam jamur tiram seperti limbah jerami. Hal ini mengingat limbah jerami yang tersedia melimpah tersebut belum dimanfaatkan dan hanya dibuang di area persawahan di kampung Cigarogol.

Melalui kegiatan ini, target yang akan dicapai adalah meningkatnya pengetahuan ibu-ibu PKK Cigarogol mengenai budidaya jamur tiram putih sehingga mereka dapat memanfaatkan waktu luangnya untuk kegiatan yang lebih produktif.

\section{B. PELAKSAAAN DAN METODE}

Kegiatan pengabdian ini dilaksanakan di kampung Cigarogol desa Mekarsari, Ciulengsi, Bogor pada bulan Mei 2018. Kegiatan ini diikuti oleh ibu-ibu rumah tangga yang tergabung dalam kelompok PKK yang berjumlah 21 orang. Metode survey dengan menggunakan angket digunakan untuk mengumpulkan data tentang pemahaman mitra tentang materi pelatihan. Selanjutnya, langkah kerja yang digunakan dalam kegiatan ini adalah pembekalan materi atau teori dasar untuk meningkatkan pemahaman terhadap budidaya jamur tiram yang dilakukan dengan cara ceramah dan diskusi, kemudian dilanjutkan dengan praktek langsung membuat media dengan bahan dasar jerami. Kegiatan praktik disesuaikan dengan materi yang diberikan sebelumnya, kecuali pembuatan bibit karena proses ini memerlukan keahlian tersendiri yang bisa diberikan setelah menguasai ketrampilan-keterampilan khusus.

Materi pengarahan berupa materi pengetahuan mengenai budidaya jamur tiram dan peluang usahanya. Materi budidaya meliputi persiapan alat dan bahan, persiapan bibit, proses sterilisasi, proses fermentasi, proses inkubasi dan proses produksi tubuh buah jamur tiram.

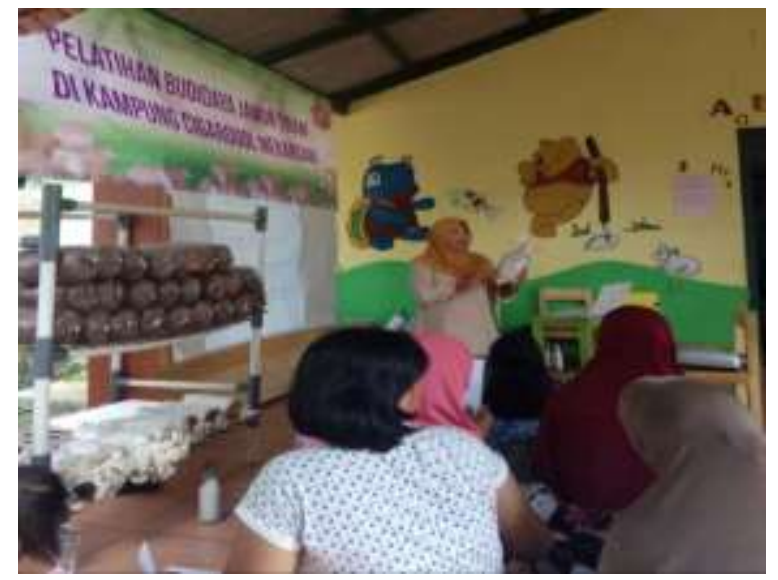

Gambar 1. Pengarahan budidaya jamur tiram

\section{HASIL DAN PEMBAHASAN}

Kegiatan pengabdian kepada masyarakat dalam upaya meningkatkan ketrampilan melalui kegiatan pelatihan budidaya jamur tiram di desa Cigarogol telah 
dilaksanakan sesuai rencana kegiatan. Sejumalah ibu rumah tangga yang menjadi mitra kurang lebih berjumlah 21 orang diberikan pelatihan tersebut. Sebelum kegiatan pelatihan, tim melakukan survey guna menyiapkan materi dan menggali pemahaman mereka tentang manfaat jerami dan jamur tiram. Angket disebarkan kepada peserta pelatihan yang berisi pertanyaan tentang tingkat pengatahuan dan ketrampilan masyarakat sekitar mengenai pengenenalan jenis jamur tiram putih, manfaat, habitat media serbuk kayu, media jerami dan budidaya jamur tiram putih. Hasil perhitungan angket yang disebarkan kepada masyarakat peserta pelatihan menunjukkan rata-rata pengetahuan dan ketrampilan awal tentang budidaya jamur tiram putih masih minim yaitu sebesar $28,1 \%$. Setelah diadakan pelatihan, pengetahuan dan ketrampilan peserta menunjukkan peningkatan mencapai angka $71,9 \%$. Hasil selengkapnya disajikan dalam grafik gambar 2 .

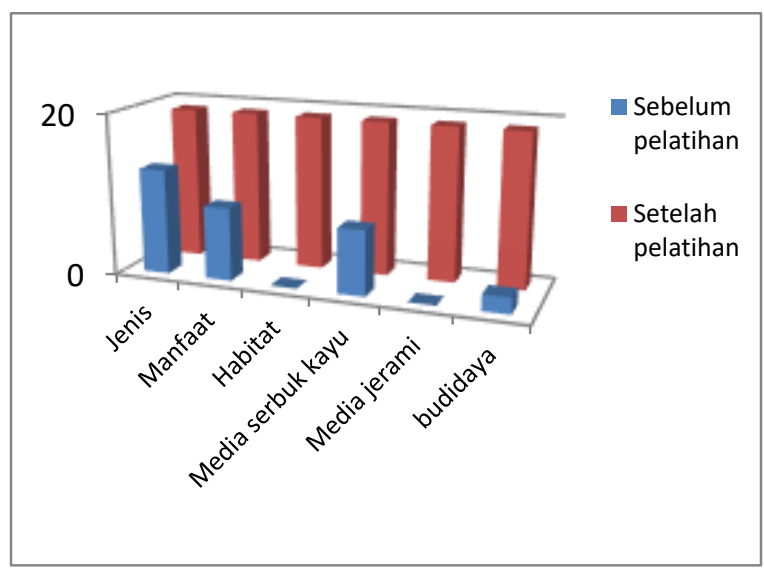

Gambar 2. Hasil perhitungan angket pengetahuan dan ketrampilan awal tentang budidaya jamur tiram putih.

Jenis Jamur Tiram

Dari hasil kegiatan diketahui bahwa pada umumnya peserta pelatihan sudah mengenal baik bentuk luar (morfologi) jamur tiram putih yaitu tudung lebar berwarna putih. Sebanyak 68,4 \% responden sudah mengetauhi bentuk jamur seperti itu adalah jamur tiram. Menurut Nugraha (2011), dikatakan jamur tiram karena mempunyai tekstur yang mirip dengan tiram (kerang) dan berwarna putih.Sebagian kecil responden hanya mengenalnya sebagai "jamur" saja atau "jamur putih" saja.

\section{Manfaat Jamur Tiram Putih}

Dilihat dari segi manfaat jamur tiram putih, sebanyak $47,4 \%$ peserta sudah mengetahui manfaat jamur tiram putih dari sisi kandungan dominannya dan juga manfaat bago kesehatan. Dari informasi responden sebelum pelatihan, mereka hanya tahu bahwa jamur tiram putih merupakan jamur yang dapat dikonsumsi dan tidak beracun. Stelah kegiatan pengabdian, mereka sudah mengetahui bahwa jamur tiram putih memiliki kandungan protein yang tinggi dan memiliki manfaat lain yaitu rasanya yang lezat dan dapat dibuat berbagai macam masakan dan camilan. Hal ini sesuai dengan pendapat Maulana (2012) yang menyebutkan bahwa nutrisi yang terkandung dalam $100 \mathrm{gr}$ jamur tiram segar terdiri atas 367 kalori, air $92,2 \%$, protein $10,5-30,4 \%$, karbohidrat $56,6 \%$, lemak 1,7-2,2\%, thiamin (Vitamin B1) 0,20 mg, riboflavin (vitamin B2) 4,7-4,9 $\mathrm{mg}$, vitamin C $36,58 \mathrm{mg}$, niacin $77,2 \mathrm{mg}$, kalsium $314 \mathrm{mg}$, zat besi $1,7 \mathrm{mg}$, serat $12 \%$ dan kadar abu 9,1\%. Kandungan protein, karbohidrat, vitamin dan mineral jamur tiram putih ini sangat baik dikonsumsi masyarakat.

Habitat jamur tiram

Seluruh peserta pelatihan pada awalnya mengenal jamur tiram hanya bisa tumbuh di daerah yang bersuhu dingin. Setelah pelatihan mereka mulai memahami bahwa jamur ini dapat berkembang di daerah yang bersuhu dingin maupun sedang, hanya saja perlu manipulasi tempat dan jumlah 
penyiraman yang berbeda dibandingakan daerah dingin. Jamur tiram putih dapat hidup pada suhu $10^{\circ} \mathrm{C}-32^{\circ} \mathrm{C}$, jika suhu kurang dari $10^{\circ} \mathrm{C}$ atau lebih dari $32^{\circ} \mathrm{C}$ maka pertumbuhan jamur tiram putih akan terhambat. Pertumbuhan jamur tiram putih akan optimum pada suhu $25^{\circ} \mathrm{C}-26^{\circ} \mathrm{C}$. Suhu optimum tersebut dapat ditemui di wilayah Indonesia yang memiliki ketinggian 5001000 mdpl (Asegab, 2011).

\section{Media Serbuk Kayu}

Salah satu faktor yang sangat memegang peranan adalah media tanam yang umumnya berupa serbuk kayu, karema jamur pada umumnya dikenal sebagai pelapuk kayu. Sebanyak 42,1 \% peserta pelatihan sudah mengenal limbah serbuk kayu sebagai media tanam jamur tiram dan diberi bahan lain berupa dedak sebagai campurannya. Menurut Istiqomah (2014), komposisi media tanam yang optimal menghasilkan berat jamur adalah serbuk kayu70 \% : bekatul 22,5 $\%$ : kapur 6\%: gips $1,5 \%$.

Pembuatan media dengan serbuk kayu dilakukan oleh ibu-ibu rumah tangga. Dengan praktek langsung, para peserta menjadi lebih mudah memahami materi yang diberikan. Selain itu antusias mereka juga nampak sekali ketika mereka praktek langsung.

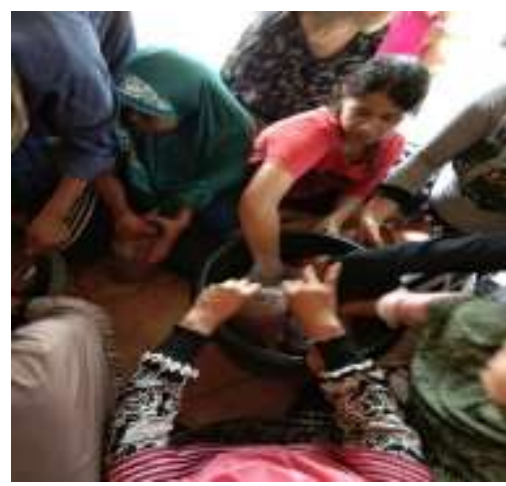

Gambar 3. Pembuatan bloglog media tumbuh dengan serbuk kayu.
Media Jerami

Pasokan serbuk kayu menjadi semakin berkurang, sehingga diperlukan alternatif media lain yang banyak mengandung bahan organik dan selulosa. Jerami juga memiliki kandungan tersebut, sehingga diharapkan pertumbuhan jamur dapat menghasilkan berat dan jumlah tubuh buah yang besar.Hasil penelitian Wahidah dan Firman (2015), menunjukkan rata-rata waktu penyebaran miselium yang lebih cepat pada limbah jerami dibandingkan dengan serbuk kayu. Semua peserta pada awalnya tidak mengetahuo bahwa jerami dapat membantu memperkaya nutrisi media jamur tiram putih. Media jerami yang bagus untuk budidaya jamur harus dibebaskan dari serangga tanah. Serangga tanah ini dapat menyebabkan pembusukan pada bibit tanaman. Menurut Andrianni dkk. (2017), meskipun serangga tanah dapat membantu menyuburkan tanah, namun serangga tersebut dapat juga menyerang tanaman.

Salah satu cara yang dilakukan untuk mengurangi hama atau serangga tanah pada media jerami adalah dengan melakukan fermentasi pada media tersebut. Fermentasi ini cukup penting sebelum dilakukan penanaman bibit karena selain membunuh hama tanah juga dapat membunh jamur liar yang dapat mengganggu pertumbuhan jamur tiram. Fermentasi dilakukan dengan cara mendiamkan media jerami pada kantong plastik tertutup selama kurang lebih 5-9 hari. Hal ini dapat membantu proses pelapukan jerami karena suhu didalam kantong plastik akan meningkat.

\section{Cara Budidaya Jamur Tiram}

Peserta pelatihan yang sudah mengetahui budidaya jamur tiram putih sebanyak dua orang (10,5\%). Kegiatan pelatihan meliputi tahapan budidaya mulai dari pengenalan bahan dan alat, komposisi 


\section{PENUTUP} inokulasi sampai dengan tahap produksi jamur. Dari seluruh proses budidaya, tahap sterilisasi merupakan tahap yang memerlukan waktu paling lama untuk mencagah terjadinya kontaminasi pada baglog jamur. Proses sterilisasi berkisar 6-10 jam seperti pada hasil penelitian (Desna dkk., 2010). Sterilisasi dilakukan pada sebuah drum seperti pada Gambar 4 berikut ini.

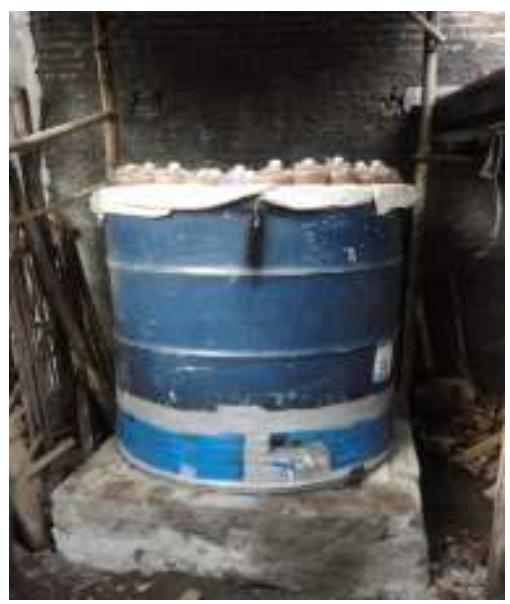

Gambar 4. Drum sterilisasi media baglog jamur

Seluruh peserta pelatihan baru memahami cara budidaya jamur tiram secara jelas melalui praktek langsung dan sekaligus pembuatan desain rumah jamur yang dipergunakan untuk mengisi hasil praktek para peserta pelatihan. Tahap pertama yang dilakukan untuk budidaya jamur adalah pemilihan bibit jamur tiram yang baik. Pada kegiatan ini, peserta diberikan penjelasan dalam memilih bibit yang baik yaitu dengan mengamati atau mencari bagian miselium yang berwarna putih dan tumbuh rata. Ciri ini adalah hal yang paling mudah untuk diketahui.

\section{Simpulan}

Tingkat pengetahuan dan ketrampilan ketrampilan masyarakat desa Desa Cigarogol Kelurahan Mekarsari Kecamatan Cileungsi Kabupaten tentang budidaya jamur tiram putih kurang yaitu sebesar $28,1 \%$. Kegiatan pelatihan budidaya Jamur tiram putih telah menambah pengetahuan dan ketrampilan masyarakat sebesar $71,9 \%$ yang meliputi pengenalan istiah jamur tiram putih sebesar $31,6 \%$, manfaat jamur tiram putih sebesar $52,6 \%$, habitat jamur tiram putih $100 \%$, media serbuk kayu untuk budidaya jamur tiram putih $57,9 \%$, media jerami sebagai alternatif budidaya jamur tiram putih $100 \%$ dan teknik budidaya jamur tiram putih $89,5 \%$. Kegiatan pelatihan sangat membantu meningkatkan pengetahuan dan ketrampilan budidaya jamur tiram putih masyarakat dan berpotensi menambah penghasilan masyarakat sekaligus menambah pasokan jamur tiram putih di pasaran.

\section{Saran}

Berdasarkan hasil dari kegiatan pengabdian yang telah dilaksanakan, penulis menyarankan untuk:

1. Dalam memberikan pelatihan kepada masyarakat yang memiliki tingkat Pendidikan rendah sebaiknya diawali dengan memberikan pemahaman tentang materi pelatihan untuk memudahkan mitra memahami dan mengikuti kegiatan dengan lancar.

2. Bagi masyarakat yang telah mendapatkan pelatihan serupa disarankan untuk selalu berkonsultasi dan berkomunikasi dengan ahli atau tim pelaksana pengabdian agar selalu memiliki pengetahun terbaru terkait materi yang telah disampaikan. 


\section{Ucapan Terima Kasih}

Terima kasih kami sampaikan kepada LPPM Universitas Muhammadiyah Prof. Dr. HAMKA yang telah membantu mendanai kegitan pelatihan ini dan kepada mitra kelompok PKK di desa Cigarogol, Ciulengsi, Bogor yang telah bersedia bekerja sama sehingga kegiatan pengabdian kepada masyarakan ini dapat berjalan dengan baik.

\section{E. DAFTAR PUSTAKA}

Andrianni, D. M., Setyaningsih, M., Susilo, Meitiyani, \& Pambudi, A.D. 2017. Keanekaragaman dan Pola Penyebaran Insekta Permukaan Tanah di Resort Cisarua Taman Nasional Gunung Gede Pangrango Jawa Barat. Jurnal Bioeduscience, 1(1), 24

Asegab. 2011. Bisnis Pembibitan Jamur Tiram, Jamur Merang dan Jamur Kuping. Jakarta. PT. AgroMedia Pustaka.

Desna,dkk. 2010. Kajian Proses Sterilisasi Media Jamur Tiram Putih Terhadap Mutu Bibit Yang Dihasilkan. Berkala Fisika Vol 13(2): 45-48.

Istiqomah, N \& Fatimah S. 2010. Pertumbuhan dan Hasil Jamur Tiram pada Berbagai Komposisi Media Tanam. Jurnal Ziraa'ah. Vol. 39(3):95-99.

Maulana, E. 2012. Panen Jamur Tiap Musim Panduan Lengkap Bisnis dan Budi Daya Jamur Tiram. Yogyakarta. Lily Publisher.

Nugraha, T. 2015. Kiat Sukses Budi Daya Jamur Tiram. Bandung: Yrama Widya.

Susilawati \& Raharjo B. 2010. Petunjuk teknis budidaya jamur tiram
(Pleourotus var florida) yang ramah lingkungan (materi pelatihan Agribisnis bagi KMPH). Sumatera Selatan. BPTP Sumatera Selatan.

Wahidah, B.F. \& Saputra. 2015. Perbedaan Pengaruh Media Tanam Serbuk Gergaji dan Jerami. Jurnal Biogenesis ISSN 2302-1616 Vol. 3(1):11-15. 